\title{
The Impact Of Deregulation On The Character Of A Firm's Board
}

Patricia L. Wollan, St. John Fisher College, USA

\begin{abstract}
This paper analyzes the impact of deregulation on board structure by comparing the boards of electric utilities before and after the passage of the Energy Policy Act (EPACT) using a unique hand-collected data set. The primary focus of the study is on changes to the boards' character, determined by the background and expertise of the directors. The results show that electric utilities change their board structure in response to their new operating environment. Boards are smaller and more independent in the later period. Also, even though the number of outside directors stays the same, there are two notable changes in the character of these directors. The number of executives from large firms and the number of directors with political backgrounds are both significantly greater after the passage of EPACT. Overall, the results are consistent with Williamson's hypothesis that firms will change the composition and character of their board in response to a change in the firm's operating environment.
\end{abstract}

Keywords: Board Structure; Board Character; Deregulation; Electric Utilities

\section{INTRODUCTION}

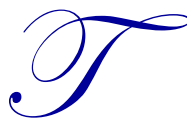

here is an increasing interest in how corporate boards evolve over time as a way to shed light on the factors that shape board composition. Some progress has been made, but many unexplained aspects still remain (Boone, Field, Karpoff, \& Raheja, 2007). To date, two components of board composition have been emphasized in the literature; namely, board size and level of independence (Coles, Daniel, \& Naveen, 2008; Link, Netter, \& Yang, 2008). By contrast, a third component - the character of the individual directors - has received little attention (Klein, 1998).

Fama and Jensen (1983) assert that "the composition and character of the board of directors will reflect the hazards facing the residual claimants." Extending this theory, Williamson (1983) hypothesizes that a change in the firm's operating environment will result in a change in the composition and character of the board of directors. The removal and relaxation of regulations in the electric utility industry provide an opportunity to test this hypothesis.

Earlier tests of Williamson's substitution hypothesis focused on differences in a firm's board composition (the relative mix of employee and non-employee directors, or insiders and outsiders) and produced mixed results (Mayers, Shivdasani, \& Smith, 1997; Brickley \& James, 1987). The underlying assumption of these tests is that boards have a single function, which is to monitor managers, and that boards with more outside directors have more monitoring power. Under this assumption, an increase in managerial discretion, or a decrease in the level of other monitoring mechanisms, should cause a firm to increase the proportion of outside directors they place on their boards. Using this assumption, Myers, Shivdasani, and Smith (1997) find support for Williamson's substitution hypothesis; by contrast, Brickley and James (1987) do not. However, in a discussion of their empirical results, Brickley and James note that outside directors can be valuable to the firm for more than just their role as monitors. They concede that the underlying assumption in their study may be too restrictive.

Despite the variety of functions performed by non-employee directors, their individual contributions have not been widely studied (Klein, 1998). In the finance literature, non-employee directors are commonly treated as a unified monitoring block, but the role of these so-called outside board members extends beyond that of 
disciplinarian. In addition to monitoring, outsider directors give advice on a variety of topics ranging from merger tactics to dealing with political processes (Mace, 1971; Agrawal \& Knoeber, 2001). Outside directors can also serve a public relations role (Pfeffer, 1976). Indeed, Pfeffer (1976) and Basinger and Zardkoohi (1986) argue that prior to deregulation, electric utilities placed more outsiders on their boards than did their non-regulated counterparts in an attempt to co-opt influential members of the local community, not because electric utilities needed more intensive monitoring.

This study adds to the growing literature that examines the evolution of corporate boards as a way of understanding the underlying factors that determine their size and level of independence (see, for example, Lehn, Patro, \& Zhao, 2009; Boone, Field, Karpoff, \& Raheja, 2007). In addition, it extends work on the impact of deregulation on board structure by examining changes in various aspects of board character, as well as independence and size. In this paper, level of independence refers to the relative mix of inside and outside directors, and character refers to a more in-depth classification of directors that attempt to recognize the varied backgrounds, expertise, and affiliations of the outside directors serving on the board.

This study is most closely related to Agrawal and Knoeber (2001) who assess the importance of political directors in a variety of industries, including the electric utility industry. The results in the paper support those of Agrawal and Knoeber for an extended sample of firms. The contribution of this paper is to assess the evolution of additional components of board character, which have been traditionally different from those of non-regulated firms.

First, the board structure of electric utilities is compared at two different points in time - 1988, four years before the passage of the Energy Policy Act (EPACT), and 2000, eight years after the bill was passed. ${ }^{1}$ These univariate tests indicate significant changes in size, composition, and the character of utilities' boards. The boards become smaller and more independent because of a significant decrease in the number of insiders. Analysis of a more detailed breakdown of the outside directors reveals an increase in two classifications - executives of Fortune 1000 corporations and, consistent with Agrawal and Knoeber (2001), ex-politicians. The numbers of directors in other classifications show little change.

Both fixed and random effects multivariate Poisson regressions were used to check the robustness of the results. After controlling for firm size, performance, and CEO tenure (Hermalin \& Wesibach, 1988; Coles, Daniel, \& Naveen, 2008), the changes identified by the simple univariate comparisons remain significant under both the random and fixed effects regressions.

Overall, the changes in board size, composition, and character are consistent with national trends in board size and composition (Lehn, Patro, \& Zhao, 2009) and the view that firms adjust their boards in response to a change in their operating environment. As the hazards facing the residual claimants of electric utilities have changed, the board has been modified to address those hazards. The increased presence of Fortune 1000 executives on the boards of electric utilities suggests that utilities responded to the increased levels of CEO discretion and job complexity by placing executives, who have the background and experience to advise and monitor him, on their boards. Also, the increase in the number of ex-politicians serving on the boards of electric utilities is consistent with the heightened need of electric utilities for advice about and influence over the political process as the industry went through a period of deregulation.

The next section provides more detail on the electric utility industry, highlighting the aspects of deregulation that have led to an increase in the challenges as well as the opportunities to be managed by electric utility executives. Subsequent sections include a discussion of factors that impact board size, composition, and character; the classification of directors, description of the data, and summary statistics for the board and the sample firms; the development of the multivariate regressions; a discussion of the results; and a conclusion.

\footnotetext{
${ }^{1}$ The Energy Policy Act (EPACT), which passed into law in 1992, increased competition at the wholesale level by requiring electric utilities to move or "wheel" electricity along their transmission lines for any producer. In addition, the Act expanded the geographic reach of utilities by allowing them to purchase independent power producers anywhere in the US and also to purchase foreign power companies. Independent power producers are merely power generators; they have no infrastructure to transmit and distribute the power they produce.
} 


\section{INDUSTRY BACKGROUND}

\section{Introduction}

The electric utility industry was partially deregulated in the 1990's. As a result, the once heavily regulated industry has been transformed. Prior to deregulation, homogeneous firms serviced captive customers in a restricted geographic territory. Following the passage of EPACT, partial deregulation enabled many of these entities to transform into diversified energy companies with non-regulated operations that span large regions of the country, or even the globe. This section highlights the major features of the more confining regulation as well as the deregulating events that caused the operating environment of electric utilities to change so much. For an encapsulated version of this discussion, see Table 1.

Table 1: Impact of Deregulation on the Operating Environment of Electric Utilities

\begin{tabular}{|l|c|c|}
\hline & Pre EPACT & Post EPACT \\
\hline Level of competition for wholesale electric power? & Minimal & Substantial \\
\hline Competition for electricity at the retail level? & No & No, but anticipated \\
\hline Electric utility monopoly over transmission lines? & Yes & Significantly reduced \\
\hline $\begin{array}{l}\text { Utilities can build or acquire non-regulated generating plants anywhere in the } \\
\text { county? }\end{array}$ & No & Yes \\
\hline Utilities can invest in or acquire foreign power companies? & No & Yes \\
\hline Market for electricity trading? & No & Yes \\
\hline Market for energy consulting? & Minimal & Expanded \\
\hline Regulatory hurdles for intra industry mergers?* & Significant & More Lenient \\
\hline Ability to merge utilities with non-contiguous operations?* & No & First approved 1997 \\
\hline $\begin{array}{l}\text { Ability for electric utilities to merge with gas companies that had interstate } \\
\text { operations?* }\end{array}$ & No & First approved 1994 \\
\hline Utilities concerned over who would pay for stranded costs? & Somewhat & Extremely \\
\hline
\end{tabular}

* A relaxing of merger restrictions was not a provision of EPACT. Rather, in the early nineties, the SEC announced that they planned to interpret PUCHA more liberally when faced with future merger requests. Since the timing of the announcement coincides with the passage of EPACT, the more liberal interpretation of PUCHA is used for merger requests in the table.

\section{Background on Regulation}

For much of the past century, the electric utility industry was heavily regulated at both the federal and state levels. Federal policies limited utilities' corporate structure, operating boundaries, and investment choices while state regulations set their geographic territories, governed their funding, limited the scope of their operations, and established what they could charge their retail customers.

The Public Utilities Holding Company Act (PUHCA), enacted in 1935, is the primary federal regulation governing electric utilities. Under PUHCA, all subsidiaries of registered holding companies have to be run as a single, integrated system. Electric utilities owned by a holding company must be interconnected and the boundaries of the operation, as a whole, cannot extend over more than a few states (Energy Information Administration, 1993). In addition to the inter-industry limitations, PUHCA restricts any registered holding company from diversification into non-related businesses and prohibits investment in foreign power companies.

For most of the last century, state regulators controlled the retail power markets. In 1877, Congress classified utilities as natural monopolies and gave them the right to operate without competition within specified geographic areas. To prevent utilities from abusing their monopolistic power, Congress authorized the states to set retail electricity rates. In addition, state regulations limited diversification for exempt holding companies operating within their borders.

\section{Deregulating Events and their Impact}

The operating environment for electric utilities began to change with the passage of the Public Utilities Regulatory Policies Act (PURPA) of 1978, though its impact was limited. Few entities could take advantage of this 
legislation, which introduced some new players into the generation business. ${ }^{2}$ It was not until the early 1990s that the major changes in utilities' operating environment began.

In 1992, the Energy Policy Act (EPACT) was passed into law. This legislation spurred competition at the wholesale level, establishing a new class of power generator, and it gave utility managers more discretion over the scope of their operations. Under EPACT, certain non-utilities - called electric wholesale generators (EWGs) - can generate power anywhere in the country, as long as they sell it wholesale. More notably, this legislation guarantees the EWGs access to the country's transmission lines; utilities are now required to transmit wholesale power upon request and they must charge a fair price for the service. Moreover, this legislation opened up the wholesale generation business to electric utilities, which are now permitted to own and operate non-utility generation plants anywhere in the US (via non-regulated subsidiaries). In addition, the passage of EPACT increased utilities' operational scope by allowing them to invest in foreign power companies.

The provisions of EPACT affected the operating environment of electric utilities directly by increasing the scope and competitiveness of industry operations, and they also heralded further change. Expansion of the wholesale market for electricity spawned two new lines of business - electricity trading and energy consulting services. A string of subsequent events further removed or relaxed regulatory constraints on competition and operating scope. ${ }^{3}$ In the early 1990's, utility executives were keenly aware that crucial political battles lay ahead of them. The most important of these were the federal and state decisions regarding stranded costs.

Stranded costs are expenses incurred under a regulatory setting that would become unrecoverable under competition. Most utilities carried stranded costs exposure in the early 1990s (Electric Utilities Week, 1995). According to Moody's, in 1993, all but eleven publicly traded electric utilities carried stranded costs on their books and about a third of them carried stranded costs that exceeded their outstanding equity. Consumer advocates argued that shareholders were responsible for these liabilities; utilities and shareholders argued that the costs should be passed on to consumers. Regulators had to make the final decision. Clearly, obtaining favorable rulings on who would bear the brunt of these costs was vital for the financial viability of most utilities.

\section{REGULATION, DEREGULATION, AND BOARD COMPOSITION}

\section{The Impact of Regulation}

Earlier studies have examined the composition and character of electric utilities' boards under regulation. Historically, these boards included more outsiders and lawyers that those of industrial firms (Pfeffer, 1976). Also, large utilities placed many local businessmen on their boards, in contrast to large industrial firms that typically selected executives of similarly sized firms as board members (Baysinger \& Zardkoohi, 1986). Pffeffer (1976) and Baysinger and Zardkoohi (1986) argue that prior to deregulation, electric utilities were attempting to co-opt influential members of the local community. This was seen as a logical strategy because activism from local consumers in the public rate setting process could negatively impact a utility's revenue.

\section{The Impact of Deregulation}

Aggrawal and Knoeber (1999) address the impact of deregulation on the board structure of electric utilities. They test whether the increased importance of political activism causes electric utilities to place additional expoliticians on their boards. Their results indicate a significant increase in such directors, suggesting that electric utilities placed additional value on political directors during a period of deregulation.

\footnotetext{
${ }^{2}$ Certain types of entities, such as co-generators that produce power as a by-product of production, and independent power producers, were permitted to generate power for the wholesale power market. The wholesale price paid for their power was regulated and utilities were required to purchase it.

${ }^{3}$ For example, in September 1992, California became the first state to explore deregulation of electricity at the retail level. In September 1996, they enacted legislation to phase in retail competition beginning in 1998. As of August 1, 2001, twenty-two states had established laws designed to phase in competition for retail electricity sales over a three to ten-year period (eight of which have subsequently been suspended). Also, beginning in the early 1990s, the SEC has adopted a more liberal interpretation of PUHCA's integration requirements in its review of merger requests. Non-contiguous utilities, as well as combination gas and electric companies from across state lines, have been permitted to merge.
} 
Post EPACT, managers have increased discretion over their existing businesses and the scope of their operations has expanded functionally and geographically. As utility managers had increasing choice over the strategic direction of their utilities, and as the business of running a utility became more competitive and complex, then ceteris paribus, under Williamson's hypothesis - the type of monitoring and the kind of advice these managers need - should be different from the optimum under more confining and limiting regulation. For an industry expanding into national and international markets, a director with experience and expertise in such markets could better evaluate the performance of the utility's management and could offer more pertinent advice than a director that runs a small business rooted in a single state. Therefore, a test was performed to assess whether electric utilities increased the number of board members associated with large, national and international firms following partial deregulation. For classification purposes, firms listed on the Fortune 1000 were used (as well as private and foreign firms of equivalent size).

\section{CLASSIFICATION OF DIRECTORS, DATA, AND SUMMARY STATISTICS}

\section{Classification of Directors}

The most common classification of directors in academic studies differentiates insiders (those who work for the firm) and outsiders (those who do not work for the firm). In this paper, directors are first categorized as either insiders or outsiders and then an additional classification scheme is used to depict the character of the outside directors. The classifications are based on the backgrounds and affiliations of the individual directors. Table 2 shows a breakdown of the outside director classifications used for the study. They fall into four basic categories - Fortune executives, non-Fortune executive, service firm executives, and non-business directors.

Table 2: Board Classification Scheme

\begin{tabular}{|l|l|l|}
\hline $\begin{array}{l}\text { The board's composition is defined to be the mix of insider and outside directors, while the character of the outside directors is } \\
\text { determined by the mix of directors in each of the following four classifications: Fortune executives, non-Fortune executives, } \\
\text { service firm executives, and non-business directors. These director classifications are shown below along with a listing of the } \\
\text { backgrounds and organizational affiliations of the directors included in each grouping. }\end{array}$ \\
\hline Composition & \multicolumn{1}{|c|}{ Character } & \multicolumn{1}{c|}{ Backgrounds and Affiliations of the Individual Directors } \\
\hline Insiders & \multicolumn{1}{|c|}{ Fortune Executives } & Active and Retired Executives of Fortune 1000 non-service firms \\
\hline \multirow{5}{*}{ Outsiders } & Non-Fortune Executives & Active and Retired Executives of smaller, non-service firms \\
\cline { 2 - 3 } & Service Firm Executives & $\begin{array}{l}\text { Lawyers, Accountants, Commercial Bankers, Insurance Company } \\
\text { Executives, Investment Bankers, Merchant Bankers, Venture Capitalists, } \\
\text { Commodity, Brokers, Financial Service Professionals - Company Emphasis } \\
\text { on Sales, Financial Analysts (Mutual Funds, Pension Plans, Investment } \\
\text { Companies), Real Estate Executives, Business Consultants, PR Specialists }\end{array}$ \\
\cline { 2 - 3 } & $\begin{array}{l}\text { Academics, including Professors and Administrators, Authors, Clergy, Ex- } \\
\text { Military with no subsequent affiliation, Administrators for non-profits, Ex- } \\
\text { Politicians with no subsequent affiliation }\end{array}$ \\
\hline
\end{tabular}

One additional classification is that of ex-politician. After leaving office, or for times between public service, these individuals pursue careers in a variety of fields. Therefore, in addition to the classification shown in Table 2, a director is also classified as an ex-politician if he or she has held an elected position in local, state, or federal politics or served in a regulatory capacity in the utility industry.

\section{Data Collection}

The sample consists of all publicly traded U.S. electric utilities for which sufficient data were available. The initial sample was comprised of all firms on Compustat with SIC codes of 4911 and 4931. After removing 25 records from an initial list of 132 - because they were not US electric utilities - 107 remained. ${ }^{4}$ Of the 107 firms, sufficient data were available for 93 of them. The eliminated firms were small and some experienced financial difficulty in the late 1980's.

${ }^{4}$ The eliminated firms included electric cooperatives, foreign power companies, and one independent power producer. 
To document changes in the character and composition of the firms' boards, detailed information on their directors was collected. The years 1988 to 2000 were chosen because this allowed a comparison of board features for the four years prior to EPACT and for up to eight years following it. When possible, data were hand-collected from proxy statements via Lexis Nexis and Global Access. For the remainder of the sample, the data were drawn from microfiche copies of the proxy statements. On the rare occasion that a proxy statement was missing, the missing year data were interpolated by using the board member data listed in the subsequent proxy.

In addition to board data, size and performance data for the sample firms were determined. Annual sales (normalized to year 2000 dollars) and firm assets (normalized to year 2000 dollars) listed on Compustat were used as a measure of firm size. To determine firm performance, the industry adjusted abnormal stock return in each year prior to the proxy year was calculated by subtracting the buy and hold firm return from the average buy and hold industry return. For this calculation, monthly return data from CRSP were used.

\section{Summary Statistics of Board Composition}

Table 3 presents summary statistics for changes in board composition. It shows the mean, median, minimum, and maximum number of directors for each of the board classifications for proxy years 1988 and 2000. These results are generated from an unbalanced panel of data. Of the 93 firms in the original sample, twenty-four were acquired over the next thirteen years, leaving 69 firms in the year 2000. Since small- and medium-sized firms were the ones acquired, the changes noted for the unbalanced panel may simply reflect differences between the firms that remain and those that were left. This possibility was checked by comparing the board characteristics of the 69 surviving firms in 1988 and 2000 using paired t-tests (not shown). The cell averages and levels of significance are almost identical to those found for the unbalanced panel. While this check suffers from a survivorship bias, it provides a robustness check of sorts for the results reported below.

Table 3: Basic Summary Statistics for Each of the Director Classifications for 1988 and 2000

The entire unbalanced sample is used. Over the thirteen-year period, the number of firms in the sample decreased from 93 to 69. The difference of means tests evaluates whether the increase or decrease in mean value is significant.

\begin{tabular}{|l||c|c|c||c|c|c||c|}
\hline \multicolumn{1}{|c||}{} & \multicolumn{3}{c||}{$\begin{array}{c}\text { Data for 1988 firms } \\
\text { 93 firms }\end{array}$} & \multicolumn{3}{c||}{$\begin{array}{c}\text { Data for 2000 } \\
\text { 69 firms }\end{array}$} & $\begin{array}{c}\text { Difference of } \\
\text { means test }\end{array}$ \\
\hline \multicolumn{1}{|c||}{} & Mean & Median & Range & Mean & Median & Range & p value \\
\hline Board Size & 11.7 & 11.5 & $8-18$ & 11.2 & 11.0 & $7-17$ & 0.104 \\
\hline Number of Insiders & 2.8 & 3 & $1-5$ & 2.1 & 2 & $1-4$ & 0.000 \\
\hline Number of Outsiders & 8.8 & 9 & $3-16$ & 9.1 & 9 & $6-15$ & 0.228 \\
\hline Number of Fortune Executives & 1.1 & 1 & $0-4$ & 1.8 & 1 & $0-5$ & 0.000 \\
\hline Number of Non-Fortune Executives & 3.0 & 3 & $0-8$ & 2.8 & 3 & $0-6$ & 0.241 \\
\hline Number of Service Firm Executives & 3.4 & 3 & $0-8$ & 3.5 & 3 & $0-8$ & 0.418 \\
\hline Number of Non-Business & 1.4 & 1 & $0-5$ & 1.4 & 1 & $0-5$ & 0.436 \\
\hline Number of Ex-Politicians & 0.4 & 0 & $0-2$ & 0.9 & 1 & $0-3$ & 0.000 \\
\hline
\end{tabular}

A difference of means test was used to assess changes in the number of board members in each category. For all but five of the classifications and sub-classifications, the mean number of directors serving on the boards changes very little (less than 0.1 per firm). The following discussion focuses on the five with an appreciable change.

The average board size decreases from 11.7 in 1988 to 11.2 in 2000 . This decrease results from a decrease in the number of insiders; the average number of insiders decreased from 2.8 to 2.1 over the period, while the average number of outsiders showed little change - from at 8.8 in 1988 and 9.1 in 2000. This result is consistent with changes in the size of utilities boards found by Rennie (2006). A reduction in the number of insiders serving on the boards of electric utilities is consistent with the general overall trend of fewer insiders serving on boards of US corporations. This trend began in the 1960's when boards of large US firms were staffed with more insiders than outsiders (Baysinger \& Butler, 1986). A gradual decline has persisted ever since (Lehn, Patro, \& Zhao, 2009). As of the late 1990's, the boards of most large US corporations were staffed with only one or two insiders (Bhagat \& Black, 1999). 
The average number of Fortune executives serving on the boards of electric utilities increased from 1.1 in 1988 to 1.8 in 2000 (see Table 3). A t-test of an increase in the mean indicates that this change is significant $(\mathrm{p}=$ 0.000). While not shown in the table, the increase in Fortune executives is gradual over the period 1988-2000. The increase in the average number of Fortune executives is somewhat balanced by a decrease in the average number of non-Fortune executives - from 3.0 to 2.8 . However, this decrease is not statistically significant $(p=0.241)$.

Finally, consistent with the work of Agrawal and Knoeber (2001), the results show a significant increase in the average number of ex-politicians serving on the boards of electric utilities - from 0.4 to $0.9(p=0.000){ }^{5}$ These changes are consistent with the view that firms will modify the character of their boards in response to a change in their operating environment.

\section{Firm Characteristics}

On a univariate basis, there are statistically significant changes in the composition and character of the boards of electric utilities. One potential reason for the changes is the overall increase in firm size. ${ }^{6}$ As shown in Table 4 Panel A, average firm sales (shown in year 2000 dollars) have increased from $\$ 2.4$ billion in 1988 to $\$ 4.4$ billion in $2000(\mathrm{p}=0.000)$ and total assets (in year 2000 dollars) increased from $\$ 6.7$ billion in 1988 to $\$ 9.8$ billion in $2000(\mathrm{p}=0.009)$ for the unbalanced panel. In the following section, controls were used for these changes by including firm size - proxied by the $\log$ of sales and $\log$ of assets (not shown) - using multivariate Poisson regressions. Results for the balanced panel (see Table 4 Panel B) show similar results.

Table 4: Summary Statistics for Firm Size and Board Member Tenure for the Years 1988 and 2000

Panel A presents the data for the unbalanced panel of 93 and 69 firms, respectively, while Panel B presents the data for the balanced panel of 69 firms. Size is measured by firm sales and firm assets in constant 2000 dollars. The average tenure figures shown in parentheses for the year 2000 include any time served on an acquired (or merged) firm's boards. The difference of means tests evaluates whether the increase or decrease in mean value is significant.

\section{Panel A}

\begin{tabular}{|c|c|c|c|c|c|c|c|}
\hline & \multicolumn{3}{|c|}{$\begin{array}{c}\text { Data for } 1988 \\
93 \text { firms }\end{array}$} & \multicolumn{3}{|c|}{$\begin{array}{c}\text { Data for } 2000 \\
69 \text { firms }\end{array}$} & \multirow{2}{*}{$\begin{array}{c}\begin{array}{c}\text { Difference of } \\
\text { means test }\end{array} \\
\text { p value } \\
\end{array}$} \\
\hline & Mean & Median & Range & Mean & Median & Range & \\
\hline Firm Sales (\$Millions) & $\$ 2,355$ & $\$ 1,470$ & $\$ 72-\$ 10,887$ & $\$ 4,422$ & $\$ 2,797$ & $\$ 70-\$ 22,461$ & 0.000 \\
\hline Firm Assets (\$Millions) & $\$ 6,666$ & $\$ 3.720$ & $\$ 74-\$ 31,636$ & $\$ 9,805$ & $\$ 6,608$ & $\$ 172-\$ 40,741$ & 0.009 \\
\hline Tenure - Insiders & 8.3 & 8.6 & $0.5-21.0$ & $\begin{array}{c}9.0 \\
(9.6) \\
\end{array}$ & $\begin{array}{c}8.5 \\
(9.3) \\
\end{array}$ & $\begin{array}{l}2.0-18.0 \\
(2.0-18.0) \\
\end{array}$ & 0.161 \\
\hline Tenure - Outsiders & 7.9 & 7.9 & $2.9-15.7$ & $\begin{array}{c}8.8 \\
(9.4) \\
\end{array}$ & $\begin{array}{c}8.7 \\
(9.0) \\
\end{array}$ & $\begin{array}{c}4.5-15.0 \\
(4.8-15.0)\end{array}$ & 0.040 \\
\hline
\end{tabular}

Panel B

\begin{tabular}{|c|c|c|c|c|c|c|c|}
\hline & \multicolumn{3}{|c|}{$\begin{array}{c}\text { Data for } 1988 \\
69 \text { firms }\end{array}$} & \multicolumn{3}{|c|}{$\begin{array}{c}\text { Data for } 2000 \\
69 \text { firms }\end{array}$} & \multirow{2}{*}{$\begin{array}{c}\begin{array}{c}\text { Difference of } \\
\text { means test }\end{array} \\
\text { p value } \\
\end{array}$} \\
\hline & Mean & Median & Range & Mean & Median & Range & \\
\hline Firm Sales (\$Millions) & $\$ 2,692$ & $\$ 1,778$ & $\$ 72-\$ 10,887$ & $\$ 4,422$ & $\$ 2,797$ & $\$ 70-\$ 22,461$ & 0.007 \\
\hline Firm Assets (\$Millions) & $\$ 7,519$ & $\$ 4,312$ & $\$ 74-\$ 31,636$ & $\$ 9,805$ & $\$ 6,608$ & $\$ 172-\$ 40,741$ & 0.073 \\
\hline Tenure - Insiders & 8.3 & 7.7 & $0.5-21.0$ & $\begin{array}{c}9.0 \\
(9.6)\end{array}$ & $\begin{array}{c}8.5 \\
(9.3)\end{array}$ & $\begin{array}{l}2.0-18.0 \\
(2.0-18.0)\end{array}$ & 0.186 \\
\hline Tenure - Outsiders & 8.3 & 7.7 & $2.9-15.7$ & $\begin{array}{c}8.8 \\
(9.4)\end{array}$ & $\begin{array}{c}8.7 \\
(9.0) \\
\end{array}$ & $\begin{array}{c}4.5-15.0 \\
(4.8-15.0)\end{array}$ & 0.039 \\
\hline
\end{tabular}

The discussion so far has focused on whether the composition and character of utilities boards have changed. A related question asks whether the pace of board member turnover has changed. In other words, has the change in operating environment resulted in an active reconfiguration of electric utility boards or have electric

\footnotetext{
${ }^{5}$ Agrawal and Knoeber (2001) found that the average number of ex-politicians serving on the boards of electric utilities increased from 0.51 in 1988 to 0.77 in 1999.

6 The electric utility industry has consolidated and electric utilities have expanded in scope. The number of publicly traded firms listed on Compustat has decreased from 107 to 84 over this period. The shock of partial deregulation, along with a more liaise faire interpretation of the merger guidelines by the SEC relating to electric utility mergers and the combination of electric and gas companies, led to a flurry of merger activity in the mid to late 1990s. In addition, the passage of EPACT has permitted to increase the scope of their operations to include investment in foreign power companies and non-regulated independent power plants. As a result, the average firm size in the industry increased.
} 
utilities waited for the incumbent board members to retire before replacing them? One indication of the pace of change in board composition is to look at the average tenure of the board members. A decrease in the average tenure would suggest that the pace of board turnover has quickened.

Table 4 Panel A shows the changes in average tenure for both inside and outside directors for the unbalanced panel. The average tenure for inside directors has increased from 8.3 in 1988 to 9.0 in 2000, though this increase is not significant. This change may be due to the reduction in the average number of inside directors. Since electric utilities have reduced insider representation on boards to an average of 1.7, these insiders are usually one or two of the following: the COO, the CEO or the Chairman (who is the retired CEO). These officers traditionally have longer board tenure than other inside director types.

More surprising is the result that the average tenure for outside directors has increased significantly. This result suggests that deregulation did not lead to a shake-up of utilities' boards. Instead, the opposite occurred. Mean tenure for outside board members increased from 7.9 years in 1988 to 8.8 years in $2000(p=0.040)$. This result does not indicate that firms actively reconfigure their boards in response to a change in their operating environment. Results for the balanced panel (see Table 4 Panel B) show similar results.

A potential explanation for the increase in average tenure of outside directors is that knowledge of the firm and the industry are important in this industry during a period of rapid change. Utilities may have chosen to retain some directors with firm and industry knowledge rather than replacing them all with directors who may know little about the industry. This explanation is consistent with the findings of Hadlock, Lee, and Parrino (2002) regarding utility CEOs. They find that electric utilities hire relatively few CEOs from outside the company. In the few cases where they do, new CEOs are recruited from other electric utilities or from the ranks of the outside board members of the electric utility (as in the case of Tucson Electric Power in 1990). This suggests that knowledge of the power business and the local operating environment may be important for both managers and directors in this industry.

\section{REGRESSION ANALYSIS - NUMBER OF DIRECTORS IN EACH CATEGORY}

\section{Poisson Regressions}

The univariate statistics from the prior section suggest that electric utilities responded to the increased scope and complexity in their environment by increasing the number of Fortune executives on their boards. However, these tests also show that that average firm size increased substantially over the same period. To check that the change in board character and composition are not driven by firm size or other potentially confounding factors, changes in board classifications were tested using random and fixed effects multivariate Poisson regressions. Such regressions are commonly used for analyzing board data. ${ }^{7}$

In addition to the primary analysis and evaluating the impact of deregulation on the number of Fortune executives and the number of ex-politicians placed on utility's boards, any changes in the other board classifications were documented as well. This analysis can confirm that apart from a decrease in the number of insiders and increases in the number of Fortune 100 directors and political directors, the number of directors in all other director categories does not change. Moreover, these regressions identify factors other than deregulation that impact the composition and character of the boards of electric utilities.

Both random and fixed effects regressions were run. Using the two methods makes it possible to tease out certain types of information. For example, using random effects regression can show whether the board composition of larger firms differs from that of smaller firms. By contrast, using fixed effects regressions can show whether an increase in firm size for a given firm has an impact on board composition and character. Random effects regressions were run for both the unbalanced panel (with 93 firms in 1988 that reduced to 69 in 2000) and the balanced sample of 69 firms. The results are not substantially different, so the regressions are reported for the unbalanced sample only.

\footnotetext{
${ }^{7}$ For example, see Hermalin and Weisbach (1988), Klein (1998), and Agrawal and Knoeber (2001).
} 
Utilities may be unable to reconfigure their boards immediately. To account for a potential lag in reaction time, the years 1988-2000 are not included in the regressions. About half the firms in this sample have staggered boards; if utilities choose to reconfigure their boards, it could take them at least three years to do so. For this reason, Poisson regressions for years 1988-1991 and 1997-2000 were used. This captures four years in a more regulated period and four years during the partial deregulation period.

The dependent variables in the Poisson regressions are the number of directors in each of the director classifications serving on the board of a given firm in a given year. The primary independent variable of interest is a deregulation dummy set to one for years 1997-2000. In addition, economic theory and the results of prior work on board composition were used to select control variables for the regressions.

Hermalin and Weisbach (1988) find that outsiders are added to boards following poor performance. Since their result suggests that recent poor performance may be correlated with a greater number of outside directors, the prior year industry adjusted abnormal return is included, using monthly return data obtained from CRSP. Firms may add inside directors toward the end of a CEO's tenure, either to give them increased exposure to the board as part of a CEO selection process (Mace, 1971) or because a CEO with greater tenure has more power over the CEO selection process and he is more likely to choose insiders (Hermalin \& Weisbach, 1997). Outsiders are more likely to be added early in a CEO's tenure when he is less powerful. CEO tenure is included in the regressions to control for these possible effects. Firm size is included because it has also been related to director choice (Pfeffer, 1976; Klein, 1998). Finally, since the dependent variable is the number of each classification of directors, board size in any given year is also included as a control variable.

\section{Random Effects - Results}

As shown in Table 5, the random effects Poison regressions produce similar results to the univariate analysis. Deregulation is related to a significant decrease in the number of insiders $(t=3.94)$ and significant increase in the number of Fortune executives $(\mathrm{t}=4.38)$ and ex-politicians $(\mathrm{t}=5.10)$.

Table 5: Poisson Regressions - Random Effects Number of Directors by Type

\begin{tabular}{|c|c|c|c|c|c|c|c|}
\hline \multicolumn{8}{|c|}{$\begin{array}{l}\text { This table presents the results of Poisson random effects regressions where the dependent variable is the number of directors } \\
\text { for each director class. The unbalanced panel of } 93 \text { to } 69 \text { firms consists of data for the years 1988-1991and 1997-2000, where } \\
\text { the later period represents the period of deregulation. A deregulation dummy is used for the years 1997-2000. LY ABRET is } \\
\text { the industry-adjusted abnormal stock return for the year prior to the one used to obtain the board data. Log of Sales is a proxy } \\
\text { for the size of the firm; this independent variable is the log of sales in year } 2000 \text { dollars. CEO tenure is calculated in years as } \\
\text { of the date of the current year proxy. T statistics are shown in parentheses. }\end{array}$} \\
\hline Variable & Insiders & Outsiders & $\begin{array}{c}\text { Fortune } \\
\text { Executives }\end{array}$ & $\begin{array}{c}\text { Non- } \\
\text { Fortune } \\
\text { Executives } \\
\end{array}$ & $\begin{array}{c}\text { Service } \\
\text { Firm } \\
\text { Executives } \\
\end{array}$ & $\begin{array}{c}\text { Non- } \\
\text { Business } \\
\text { Directors } \\
\end{array}$ & $\begin{array}{c}\text { Ex- } \\
\text { Politicians }\end{array}$ \\
\hline Deregulation & $\begin{array}{l}-.2485 \\
(-3.94)\end{array}$ & $\begin{array}{l}.0679 \\
(2.57) \\
\end{array}$ & $\begin{array}{l}.3305 \\
(4.38) \\
\end{array}$ & $\begin{array}{l}.0472 \\
(0.98)\end{array}$ & $\begin{array}{l}.0194 \\
(0.36) \\
\end{array}$ & $\begin{array}{l}.0190 \\
(0.26)\end{array}$ & $\begin{array}{l}.5486 \\
(5.10)\end{array}$ \\
\hline LY ABRET & $\begin{array}{l}-.2415 \\
(-1.38)\end{array}$ & $\begin{array}{l}.0467 \\
(0.51)\end{array}$ & $\begin{array}{l}-.0116 \\
(-0.05)\end{array}$ & $\begin{array}{l}.0855 \\
(0.66)\end{array}$ & $\begin{array}{l}.1511 \\
(0.99)\end{array}$ & $\begin{array}{l}.0104 \\
(0.06)\end{array}$ & $\begin{array}{l}.1059 \\
(0.39)\end{array}$ \\
\hline Log of Sales & $\begin{array}{l}.0338 \\
(1.02) \\
\end{array}$ & $\begin{array}{l}-.0050 \\
(-0.38) \\
\end{array}$ & $\begin{array}{l}.3578 \\
(4.39) \\
\end{array}$ & $\begin{array}{l}-.1476 \\
(-3.46) \\
\end{array}$ & $\begin{array}{l}-.0001 \\
(-0.97) \\
\end{array}$ & $\begin{array}{l}.2404 \\
(3.24) \\
\end{array}$ & $\begin{array}{l}.2405 \\
(2.16) \\
\end{array}$ \\
\hline CEO tenure & $\begin{array}{l}.0002 \\
(0.03)\end{array}$ & $\begin{array}{l}-.0010 \\
(-0.33)\end{array}$ & $\begin{array}{l}.0038 \\
(0.43)\end{array}$ & $\begin{array}{l}-.0085 \\
(-1.44) \\
\end{array}$ & $\begin{array}{l}-.0021 \\
(-0.32)\end{array}$ & $\begin{array}{l}.0110 \\
(1.32)\end{array}$ & $\begin{array}{l}-.0120 \\
(-1.00)\end{array}$ \\
\hline Board Size & $\begin{array}{l}.0506 \\
(3.6)\end{array}$ & $\begin{array}{c}.0885 \\
(15.40) \\
\end{array}$ & $\begin{array}{l}.0684 \\
(3.39) \\
\end{array}$ & $\begin{array}{l}.0896 \\
(6.26) \\
\end{array}$ & $\begin{array}{l}.0989 \\
(6.69) \\
\end{array}$ & $\begin{array}{l}.0869 \\
(4.36) \\
\end{array}$ & $\begin{array}{l}.0989 \\
(3.15) \\
\end{array}$ \\
\hline Constant & $\begin{array}{l}.1304 \\
(0.53) \\
\end{array}$ & $\begin{array}{c}1.174 \\
(12.68) \\
\end{array}$ & $\begin{array}{l}-3.441 \\
(-5.65) \\
\end{array}$ & $\begin{array}{l}1.050 \\
(3.79) \\
\end{array}$ & $\begin{array}{l}.0747 \\
(0.40) \\
\end{array}$ & $\begin{array}{l}-2.564 \\
(-4.73) \\
\end{array}$ & $\begin{array}{l}-3.697 \\
(-4.30) \\
\end{array}$ \\
\hline No. of Observations & 687 & 687 & 569 & 687 & 392 & 613 & 443 \\
\hline Wald $\chi^{2}$ & 42.39 & 297.88 & 66.49 & 43.29 & 46.35 & 43.53 & 46.04 \\
\hline
\end{tabular}


As expected, firm size has a substantial impact on the composition and character of the boards of electric utilities. First, size is negatively related to the number of non-Fortune executives that utilities place on their boards $(\mathrm{t}$ $=3.46$ ). This result has a plausible explanation. It seems reasonable that small firms will choose more executives from small firms as board members and vice versa.

Firm size is positively related to the number of Fortune executives $(t=4.39)$, the number of non-business executives $(t=3.24)$, and the number of ex-politicians $(t=2.16)$ on the boards of electric utilities. Larger firms may be in a stronger position to attract Fortune executives and ex-politicians to their boards, though they probably have less need for specialized financial advice since they already have teams of such experts on staff. Instead, larger firms may seek increased legitimacy by placing consumer advocates and academics on their boards.

\section{Fixed Effects - Results}

The results of the fixed effects models provide additional constraints on the data and, not surprisingly, they produce less significant results (see Table 6). However, the primary results of the univariate analysis do hold over to the fixed effects model. There is a significant decrease in the number of insiders $(t=3.66)$ and a significant increase in the number of Fortune executives $(t=4.74)$ and ex-politicians $(t=4.85)$ serving on the boards of electric utilities subsequent to deregulation. One result here is particularly informative; namely, the impact of firm size on the number of outside directors. In the random effects model, firm size is positively related to the number of Fortune executives. By contrast under the fixed effects model, no such relationship exists. This suggests that while larger firms tend to hire more Fortune executives overall, an increase in firm size for the average firm within the sample does not lead to an increase in the number of Fortune executives serving on the board.

Table 6: Poisson Regressions - Fixed Effects

Number of Directors by Type

\begin{tabular}{|c|c|c|c|c|c|c|c|}
\hline \multicolumn{8}{|c|}{$\begin{array}{l}\text { This table presents the results of Poisson fixed effects regressions where the dependent variable is the number of directors for } \\
\text { each director class. The unbalanced panel of } 93 \text { to } 69 \text { firms consists of data for the years 1988-1991 and 1997-2000, where the } \\
\text { latter period represents the period of deregulation. A deregulation dummy is used for the years 1997-2000. LY ABRET is the } \\
\text { industry-adjusted abnormal stock return for the year prior to the one used to obtain the board data. Log of Sales is a proxy for } \\
\text { the size of the firm; this independent variable is the log of sales in year } 2000 \text { dollars. CEO tenure is calculated in years as of } \\
\text { the date of the current year proxy. T statistics are shown in parentheses. }\end{array}$} \\
\hline Variable & Insiders & Outsiders & $\begin{array}{c}\text { Fortune } \\
\text { Executives }\end{array}$ & $\begin{array}{c}\text { Non- } \\
\text { Fortune } \\
\text { Executives }\end{array}$ & $\begin{array}{c}\text { Service } \\
\text { Firm } \\
\text { Executives }\end{array}$ & $\begin{array}{c}\text { Non- } \\
\text { Business } \\
\text { Directors }\end{array}$ & $\begin{array}{c}\text { Ex- } \\
\text { Politicians }\end{array}$ \\
\hline Deregulation & $\begin{array}{c}.2231 \\
(-3.66)\end{array}$ & $\begin{array}{l}.5021 \\
(1.68)\end{array}$ & $\begin{array}{l}.3906 \\
(4.74)\end{array}$ & $\begin{array}{l}-.0062 \\
(-0.11)\end{array}$ & $\begin{array}{l}-.0304 \\
(-0.22)\end{array}$ & $\begin{array}{l}.0718 \\
(0.90)\end{array}$ & $\begin{array}{l}.5587 \\
(4.85)\end{array}$ \\
\hline LY ABRET & $\begin{array}{l}-.1332 \\
(-0.86)\end{array}$ & $\begin{array}{l}.0439 \\
(0.56)\end{array}$ & $\begin{array}{c}.0075 \\
(10.03)\end{array}$ & $\begin{array}{l}.0762 \\
(0.58)\end{array}$ & $\begin{array}{l}.1001 \\
(0.30)\end{array}$ & $\begin{array}{l}.0019 \\
(0.10)\end{array}$ & $\begin{array}{l}.1882 \\
(0.69)\end{array}$ \\
\hline Log of Sales & $\begin{array}{l}-.0183 \\
(1.18)\end{array}$ & $\begin{array}{l}.0391 \\
(0.67)\end{array}$ & $\begin{array}{l}.1725 \\
(1.14)\end{array}$ & $\begin{array}{l}.0469 \\
(0.44)\end{array}$ & $\begin{array}{l}.2998 \\
(1.11)\end{array}$ & $\begin{array}{l}.0941 \\
(0.59)\end{array}$ & $\begin{array}{l}.1820 \\
(1.85)\end{array}$ \\
\hline CEO tenure & $\begin{array}{l}-0.010 \\
(-0.16)\end{array}$ & $\begin{array}{l}.0001 \\
(0.03)\end{array}$ & $\begin{array}{l}.0035 \\
(0.38)\end{array}$ & $\begin{array}{l}-.0058 \\
(-.095)\end{array}$ & $\begin{array}{l}.0074 \\
(0.49)\end{array}$ & $\begin{array}{l}.0117 \\
(1.34)\end{array}$ & $\begin{array}{l}-.0120 \\
(-0.98)\end{array}$ \\
\hline Board Size & $\begin{array}{l}.0658 \\
(3.64)\end{array}$ & $\begin{array}{l}.0829 \\
(9.00)\end{array}$ & $\begin{array}{l}.0703 \\
(3.22)\end{array}$ & $\begin{array}{l}.0840 \\
(4.87)\end{array}$ & $\begin{array}{l}.1191 \\
(2.90)\end{array}$ & $\begin{array}{l}.0980 \\
(4.46)\end{array}$ & $\begin{array}{l}.0866 \\
(2.56)\end{array}$ \\
\hline No. of Observations & 687 & 687 & 569 & 687 & 392 & 613 & 443 \\
\hline Wald $\chi^{2}$ & 44.54 & 86.44 & 40.47 & 26.07 & 11.92 & 24.82 & 36.75 \\
\hline
\end{tabular}

\section{CONCLUSION}

This paper evaluates the impact of deregulation on the board structure of electric utilities. In most studies of board structure, the measure of interest is board composition, or the relative mix of inside and outside directors. However, prior studies that compare corporate board structure in different operating environments suggest that a more in-depth classification of corporate boards is warranted. What makes the study of the electric utility industry useful in this regard is that the specific shocks transforming the industry make it possible to predict desirable changes in the characteristics of those serving on utility's boards. 
The results show that electric utilities gradually changed the character of their boards in a way that is consistent with their economic needs, by increasing the number of directors in two key categories. As their operations increased in scope and became more complex, electric utilities increased the number of executives from large firms that serve on their boards. In addition, during a time when political activism is particularly important, they placed more ex-politicians on their boards.

Overall, the results of this study corroborate with the view of Fama and Jensen (1983) that corporations pay attention to both the composition and the character of their boards. Moreover, the results support Williamson's hypothesis that firms react to a change in operating environment by reconfiguring their board structure.

\section{AUTHOR INFORMATION}

Patricia Wollan is an Assistant Professor at St. John Fisher College. She obtained her BSc in Mathematics from York University, her MBA from Old Dominion University and her PhD in Business Administration from the Pennsylvania State University. Dr. Wollan's current research interests include corporate governance, corporate restructuring, and personal financial planning. Her research has been published in the Advances in Quantitative Analysis of Finance and Accounting and the Southern Business Review. E-mail: pwollan@sjfc.edu

\section{REFERENCES}

1. Agrawal, A., \& Knoeber, C. R. (2001). Do some directors play a political role? Journal of Law and Economics, 44(1), 179-198.

2. Baysinger, B. D., \& Zardkoohi, A. (1986). Technology, residual claimants, and corporate control. Journal of Law, Economics and Organization, 2(2), 339-349.

3. Bhagat, S., \& Black, B. (May 1999). The uncertain relationship between board composition and firm performance. The Business Lawyer, 54, 921-963.

4. Boone, A. L., Field, L. C., Karpoff, J. M., \& Raheja, C. G. (2007). The determinants of corporate board size and composition: An empirical analysis. Journal of Financial Economics, 85, 66-101.

5. Brickley, J. A., \& James, C. (1987). The takeover market, corporate board composition and ownership structure: The case of banking. Journal of Law and Economics, 30, 161-180.

6. Coles, J., Daniel, N., \& Naveen, L. (2008). Boards: Does one size fit all? Journal of Financial Economics, 87, 329-356.

7. Electric Utilities Week (1995, August 14). Restructuring: Moody's report predicts $\$ 135$ billion in stranded costs over next 10 years.

8. Energy Information Administration (1993, January). Public Utility Holding Company Act of 1935: 19351992.

9. Fama, E. F., \& Jensen, M. C. (1983). Separation of ownership and control. Journal of Law and Economics, 26, 301-325.

10. Hadlock, C. J., Lee, S. D., \& Parrino, R. (2002). CEO Careers in regulated environments: Evidence from electric and gas utilities. Journal of Law and Economics, 45(2), Part 1.

11. Hermalin, Benjamin E., and Michael S. Weisbach (1988), The determinants of board composition, RAND Journal of Economics, 19, 589-606.

12. Hermalin, B. E., \& Weisbach, M. S. (1997). Endogenously chosen boards of directors and their monitoring of the CEO. American Economic Review, 88(1), 96-118.

13. Klein, A. (1998). Affiliated directors: Puppets of management or effective directors. (Working Paper) Stern School of Business, New York University.

14. Lehn, K. M., Patro, S., \& Zhao, M. (2009), Determinants of the size and structure of corporate boards: 1935 - 2000. Financial Management, 38, 747-780.

15. Link, J., \& Netter, J., \& Yang, T. (2008). The determinants of board structure. Journal of Financial Economics, 87, 308-328.

16. Mace, M. L. (1971). Directors: Myth and reality. Harvard Business School Press, Boston.

17. Mayers, D., Shivdasani, A., \& Smith Jr., C. W. (1997). Board composition and corporate control: Evidence from the insurance industry. Journal of Business, 70, 33-62. 
18. Pfeffer, J. (1976). Size and composition of corporate boards of directors: The organization and its environment. Administrative Science Quarterly, 17, 218-228.

19. Rennie, C. G. (2006). Governance structure changes and product market competition: Evidence from U.S. electric utility deregulation. Journal of Business, 77, 1989-2017.

20. Williamson, O. E. (1983). Organization form, residual claimants, and corporate control. Journal of Law and Economics, 26, 351-366. 